Original Research Article

\title{
A questionnaire based survey on the knowledge, attitude and practices about antimicrobial resistance and usage among the MBBS students and doctors of a tertiary care teaching Hospital in Silchar, Assam, India
}

\author{
Ali N. Yashin ${ }^{1}$, Nishanta Thakuria ${ }^{1 *}$, Hiranmoy Narzary $^{2}$, Dinesh Satnami ${ }^{2}$, Nilanjan Paul ${ }^{2}$
}

${ }^{1}$ Department of Pharmacology,

${ }^{2}$ Students, Silchar Medical

College, Assam, India

Received: 06 June 2018

Accepted: 28 June 2018

*Correspondence to:

Dr. Nishanta Thakuria,

Email: dr.nyshanta@yahoo.co.in

Copyright: (c) the author(s), publisher and licensee Medip Academy. This is an openaccess article distributed under the terms of the Creative Commons Attribution NonCommercial License, which permits unrestricted noncommercial use, distribution, and reproduction in any medium, provided the original work is properly cited.

\begin{abstract}
Background: Antimicrobials are agents used to kill or inhibit growth of microorganisms. Now they are most commonly used as well as misused medicine too. Misuse of these agents lead to development of resistance which is now a global concern. Public awareness about antimicrobial resistance is a key factor in combating the situation which includes educating doctors and health care professionals. So the current study is undertaken to assess the knowledge, attitude and practices (KAP) related to antibiotic resistance and usage and among the MBBS students and doctors.

Methods: A pre-formed duly validated questionnaire was distributed among the study group and their KAP regarding antimicrobial usage and resistance was assessed by Likert scale whose responses ranges from strongly agree to strongly disagree and always to never. Some questions were of true/false type. One question was choosing the correct answer. In this study, questionnaires were distributed among 270 participants out of which 188 were MBBS students and 82 were doctors. After collection, data were entered in Microsoft excel and simple descriptive statistics were used to generate frequencies, percentage and proportions. Wherever possible the chi-square test or fisher exact test was done to find out any association. $* \mathrm{p}<0.05$ was taken as significant.

Results: Response rate was $100 \%$ among the study populations. Out of 270 study population, 91\% (245) had the knowledge that indiscriminate use of antibiotics cause ineffective treatment with a considerable difference in knowledge between undergraduates and doctors $(\mathrm{p}<0.05)$. Also it causes bacterial resistance $(96.3 \%)$. Around $89 \%$ of the total participants agreed that bacteria do not cause common cold and influenza.

Conclusions: This study revealed that most of the study population, both undergraduates and doctors were well aware about the emerging problem of antimicrobial resistance. However, responses related to their practices were quite varied. Hence, further educational interventions are needed to improve their practices towards antibiotics use in both the study groups.
\end{abstract}

Keywords: Attitude, Antimicrobial resistance, Doctors, Knowledge, Practices, Undergraduates

\section{INTRODUCTION}

Antimicrobial agents are group of drugs which are basically used to kill or inhibit the growth of microorganism. ${ }^{1}$ They are most commonly prescribed medicines and are often too misused. ${ }^{2}$ As a result of injudicious use of antimicrobial agents can lead to the development of resistance which is an important growing global health issue which needs urgent reporting. First step towards curtailing the development of resistance is the public awareness. To meet the challenges various approaches have been adopted worldwide. One of them is 
educating general population, as well as health care personals about antibiotic resistance. ${ }^{3,4}$ Medical practitioners can play a major role in combating antimicrobial agent resistance. Knowledge, attitude and practice (KAP) study of medical practitioners regarding antimicrobial resistance can help us in planning an effective educational tool for them. ${ }^{5}$ The significance of conducting this study lies in the fact that similar kind of studies have never been done in Silchar Medical College and Hospital previously. Hence the main objective of the study is to assess the knowledge, attitude and practices (KAP) related to antibiotic resistance and usage among the MBBS students and doctors in Silchar Medical College and Hospital, Assam.

\section{METHODS}

This study was a cross-sectional, questionnaire based survey which was undertaken in Silchar medical college and hospital among undergraduates and doctors for a period of three months (July 2016-September 2016). The questionnaire which we used was developed by modifying the earlier ones which were used by Manali Mahajan et al, and Khan AK et al.

The final questionnaire consisted of 29 questions. Before the main survey, a pilot study was conducted with primary manuscript among the targeted populations. Based on the results of pilot study the questionnaire was modified and improved on advice of subject experts. Before the initiation of the study permission from institutional ethics committee was taken. Every participant was given a time period of 30 minutes to answer the questionnaire by choosing the right options which he/she feels to be appropriate. Questionnaires were filled anonymously. Also from each participant informed consent was taken to utilise their data for research purpose.

The participants knowledge (Table 1) was assessed by using a set of 8 questions, 6 questions of these are true/false type, one was a 5 point Likert scale based question whose response graded from strongly agree to strongly disagree. One question was choosing the correct answer from multiple answers. Attitude (Table 2) part contained 7 questions and was evaluated by 5 point Likert scale whose responses graded from strongly agree to strongly disagree. Practice (Table 3) part contained set of 3 questions and they were evaluated by 4 point Likert scale and responses graded from always to never.

In order to simplify the analysis, we reduced the 5 point and 4 point response option of the Likert scale into 3 such as agree/disagree/undecided and yes/no/uncertain. The possible answers "strongly agree" and "somewhat agree" were considered as "agree" while "strongly disagree" and "somewhat disagree" were considered as "disagree" and remaining were undecided. Similarly, the possible answers "always" and "usually" were considered as "yes" while the answer "never" were considered as "no" and "sometimes considered as "uncertain".

Table 1: Knowledge questions.

\begin{tabular}{|c|c|c|}
\hline Q. No & & s (Reply with True/ False) \\
\hline \multirow{6}{*}{1} & \multicolumn{2}{|c|}{ Indiscriminate and injudicious use of antimicrobials can lead to: } \\
\hline & A & Ineffective treatment \\
\hline & B & Increase adverse effect \\
\hline & $\mathrm{C}$ & Exacerbation or prolongation of illness \\
\hline & $\mathrm{D}$ & Emergence of bacterial resistance \\
\hline & E & additional burden of medical cost to the patient \\
\hline 2 & & If taken too often, antimicrobials are less likely to work in the future \\
\hline 3 & & Bacteria cause common cold and influenza. \\
\hline 4 & & Effectiveness of treatment is reduced if full course of antimicrobial is not completed. \\
\hline 5 & & Antimicrobial treatment should be stopped once the symptoms are improved. \\
\hline 6 & & Preferably use rapidly acting and selective narrow spectrum antimicrobial agents whenever possible \\
\hline \multirow{4}{*}{7} & & $\begin{array}{l}\text { obial Resistance is (reply with: strongly agree/somewhat agree/ undecided/somewhat } \\
\text { strongly disagree) }\end{array}$ \\
\hline & A & An important and serious public health issue facing the world. \\
\hline & B & An important and serious public health issue in our country. \\
\hline & $\mathrm{C}$ & An important and serious public health issue in our hospital \\
\hline \multirow{8}{*}{8} & & Cause of antimicrobial resistance is/are: (Tick the correct answer) \\
\hline & & - Incomplete course \\
\hline & & - Incorrect selection of antimicrobials \\
\hline & & - Lower dosing \\
\hline & & - Poor quality \\
\hline & & - Over prescribing and consumption \\
\hline & & - $\quad$ All of the above \\
\hline & & - None of the above \\
\hline
\end{tabular}


Table 2: Attitude questions.

\begin{tabular}{|ll|}
\hline & $\begin{array}{l}\text { Reply with: (strongly agree/ somewhat agree/ } \\
\text { undecided/ somewhat disagree/ strongly } \\
\text { disagree) }\end{array}$ \\
\hline 1 & $\begin{array}{l}\text { Antimicrobials are safe drugs; hence they can be } \\
\text { commonly used medication }\end{array}$ \\
\hline 2 & $\begin{array}{l}\text { Skipping one or two doses does not contribute to } \\
\text { the development of antimicrobial resistance }\end{array}$ \\
\hline 3 & $\begin{array}{l}\text { Antimicrobial prescriptions should be based on } \\
\text { culture and sensitivity report. }\end{array}$ \\
\hline 4 & $\begin{array}{l}\text { Knowledge on rationale use of antimicrobial is } \\
\text { essential for all doctors, nurses, pharmacist and } \\
\text { health care providers. }\end{array}$ \\
\hline 5 & \begin{tabular}{l} 
Do you think there is abuse of antimicrobials \\
\hline 6
\end{tabular} \\
\hline 7 & $\begin{array}{l}\text { Is abuse of antimicrobials the main cause of } \\
\text { bacterial infection }\end{array}$ \\
\hline 7 & Can antimicrobial resistance affect health \\
\hline
\end{tabular}

In this study questionnaire were distributed among 270 participants out of which 188 were medical students and 82 were doctors. After collection data were entered in Microsoft excel and simple descriptive statistics were used to generate frequencies, percentage and proportions. Wherever possible the chi square test or fisher exact test was done to find out any association. ${ }^{*} \mathrm{p}<0.05$ was taken as significant.

\section{RESULTS}

The response rate was $100 \%$ among the 270 participants where 188 were undergraduates and 82 were doctors. The results are tabulated as percentage in Table 4 , Table 5 and Table 6.

Out of all the participants $91 \%$ (245) agreed that indiscriminate and injudicious use of antimicrobial agents leads to ineffective treatment where $87.2 \%$ (164) are undergraduate students and $98.8 \%$ (81) are doctors with $\mathrm{p}$ value $<0.05$ which is statistically significant. Around $86.3 \%$ (233) (UGs $=87.8 \%$ and doctors $=83 \%)$ were aware that increase adverse effect of antimicrobials were also due to its indiscriminate uses, around 66\% (124) UGs and $84.2 \%$ (69) (p value $<0.05$ ) doctors agreed that it can cause prolongation of illness. Regarding emergence of resistance total $96.3 \%$ (260) believed that it is due to injudicious use of AMA where $94.6 \%$ (178) are UGs and 100\% (82) are doctors. 93\% (250) of the total participants agreed that it put some additional burden of medical cost to the patient. 95\% (250) of total where $92.6 \%$ (176) UGs and 96.4\% (80) doctors believed that if an AMA is taken too often it is less likely to work in future. $88.9 \%$ (240) of total responders were aware that common cold and influenza were not caused by bacteria with $\mathrm{p}$ value $<0.05$ which is statistically significant between both the groups. Around 94\% (254) believed that effectiveness of treatment is reduced if full course of AMA is not taken. 87\% (235) of the total responders were aware of the fact that antimicrobial treatment should not be stopped once the symptoms improved. $83.7 \%$ (226) of total believed that it is better to use a rapidly acting and narrow spectrum AMA. Regarding antimicrobial resistance more than $95 \%$ of total participants agreed that it is an important and serious public health issue facing the world and our country whereas only $83.3 \%$ (225) agreed that it is a serious health issue in this hospital but among the doctors 95.2\% (78) agreed that AMA resistance is a serious health issues in this hospital too. $64.9 \%$ (175) of total study population believed that antimicrobial resistance is due to multiple reasons like incomplete course, incorrect selection, lower dosing, poor quality and over consumption of antimicrobials.

However, the attitude of the study populations regarding to antibiotics use and resistance was very casual and lax. Around $37.8 \%$ (102) of total participants still agreed that antimicrobials are safe drugs and hence can be commonly used medicine where $44.7 \%$ (84) are UGs and $25.6 \%$ (21) are doctors while $54.8 \%$ (148) of total disagreed to this statement. Likewise, $40.8 \%$ (110) of the total responders still agreed that skipping one or two doses of AMA are not associated with development of resistance.

However, 92.7\% (250) of total study population agreed that antimicrobial prescription should be based on culture and sensitivity report. Knowledge of rationale use of AMA is essential for all doctors and medical students and $96.3 \%$ (260) of the total agreed to this statement. But only around $73.7 \%$ (199) of total study population agreed that there is abuse of AMA and only around $47.8 \%$ (129) agreed that abuse of AMA is the main cause of bacterial infection. $94.4 \%$ (255) of total population including 93.1\% (175) UGs and $97.5 \%$ (80) doctors strongly agreed that antimicrobial resistance can affect health.

Table 3: Practice questions.

\begin{tabular}{|c|c|}
\hline Q. No & Reply with (: always/ usually/ sometimes/ never) \\
\hline \multirow{6}{*}{1.} & The doctor prescribes a course of antimicrobial for you. After taking 2-3 doses you start feeling better. \\
\hline & A Do you stop taking the further treatment? \\
\hline & Do you save the remaining antimicrobials for the next time you get sick? \\
\hline & Do you discard the remaining, leftover medication? \\
\hline & Do you give the leftover antimicrobials to your friend/roommate if they get sick? \\
\hline & Do you complete the full course of treatment? \\
\hline 2 & Do you check the expiry date of the antimicrobials before using it? \\
\hline 3 & Do you prefer to take an antimicrobial when you have cough and sore throat? \\
\hline
\end{tabular}


Table 4: Participants knowledge regarding antimicrobial resistance and usage $(\mathrm{n}=\mathbf{2 7 0})$.

\begin{tabular}{|c|c|c|c|c|c|}
\hline \multicolumn{3}{|l|}{ Q. No } & Total $(\mathbf{N}) \%$ & Undergraduates (N)\% & Doctors $(\mathbf{N}) \%$ \\
\hline \multicolumn{6}{|l|}{$\begin{array}{l}\text { 1. Indiscriminate and injudicious use of } \\
\text { antimicrobials can lead to }\end{array}$} \\
\hline \multirow{2}{*}{\multicolumn{2}{|c|}{ a. Ineffective treatment }} & $\mathrm{T}$ & $(245) 91 \%$ & $(164) 87.2 \%$ & $(81) 98.8 \%$ \\
\hline & & $\mathrm{F}$ & $(25) 9 \%$ & $(24) 12.8 \%$ & (1) $1.2 \%$ \\
\hline \multirow{2}{*}{\multicolumn{2}{|c|}{ b. Increase adverse effect }} & $\mathrm{T}$ & $(233) 86.3 \%$ & $(165) 87.8 \%$ & $(68) 83 \%$ \\
\hline & & $\mathrm{F}$ & $(37) 13.7 \%$ & $(23) 12.2 \%$ & (14) $17 \%$ \\
\hline \multirow{2}{*}{\multicolumn{2}{|c|}{ c. Prolongation of illness }} & $\mathrm{T}$ & $(193) 71.5 \%$ & $(124) 66 \%$ & $(69) 84.2 \%$ \\
\hline & & $\mathrm{F}$ & $(77) 28.5 \%$ & $(64) 34 \%$ & (13) $15.8 \%$ \\
\hline \multirow{2}{*}{\multicolumn{2}{|c|}{ d. Emergence of resistance }} & $\mathrm{T}$ & $(260) 96.3 \%$ & $(178) 94.6 \%$ & $(82) 100 \%$ \\
\hline & & $\mathrm{F}$ & (10)3.7\% & $(10) 5.4 \%$ & $(0) 0 \%$ \\
\hline \multirow{2}{*}{\multicolumn{2}{|c|}{ e. Additional burden }} & $\mathrm{T}$ & $(250) 93 \%$ & $(170) 90.4 \%$ & $(80) 97.6 \%$ \\
\hline & & $\mathrm{F}$ & $(20) 7 \%$ & $(18) 9.6 \%$ & (2) $2.4 \%$ \\
\hline \multirow{2}{*}{\multicolumn{2}{|c|}{$\begin{array}{l}\text { 2. If taken too often, antimicrobials are less likely to } \\
\text { work in future }\end{array}$}} & $\mathrm{T}$ & $(256) 95 \%$ & $(176) 92.6 \%$ & $(80) 96.4 \%$ \\
\hline & & $\mathrm{F}$ & $(14) 5 \%$ & $(12) 7.4 \%$ & (2)3.6\% \\
\hline \multirow{2}{*}{\multicolumn{2}{|c|}{ 3. Bacteria cause common cold and influenza }} & $\mathrm{T}$ & $(30) 11.1 \%$ & $(26) 13.8 \%$ & (4)3.7\% \\
\hline & & $\mathrm{F}$ & $(240) 88.9 \%$ & $(162) 86.2 \%$ & (78)96.3\% \\
\hline \multirow{2}{*}{\multicolumn{2}{|c|}{$\begin{array}{l}\text { 4. Effectiveness of treatment is reduced if full course } \\
\text { of antimicrobial is not completed }\end{array}$}} & $\mathrm{T}$ & $(254) 94 \%$ & $(179) 95.2 \%$ & $(75) 91.5 \%$ \\
\hline & & $\mathrm{F}$ & $(16) 6 \%$ & (9) $4.8 \%$ & (7) $8.5 \%$ \\
\hline \multirow{2}{*}{\multicolumn{2}{|c|}{$\begin{array}{l}\text { 5. Antimicrobial treatment should be stopped once the } \\
\text { symptoms are improved }\end{array}$}} & $\mathrm{T}$ & $(35) 13 \%$ & $(25) 13.3 \%$ & $(10) 8.5 \%$ \\
\hline & & $\mathrm{F}$ & $(235) 87 \%$ & $(163) 86.7 \%$ & (72)91.5\% \\
\hline \multirow{2}{*}{\multicolumn{2}{|c|}{$\begin{array}{l}\text { 6. Preferrably use rapidly acting and selective narrow } \\
\text { spectrum antimicrobial agents when possible }\end{array}$}} & $\mathrm{T}$ & $(226) 83.7 \%$ & $(155) 82.4 \%$ & $(71) 86.6 \%$ \\
\hline & & $\mathrm{F}$ & $(44) 16.3 \%$ & $(33) 17.6 \%$ & (11) $13.4 \%$ \\
\hline \multicolumn{6}{|c|}{ 7. Antimicrobial resistance } \\
\hline \multirow{3}{*}{$\begin{array}{l}\text { a.) An important and serious public } \\
\text { health issue facing the world }\end{array}$} & \multicolumn{2}{|l|}{ Agree } & $(258) 95.9 \%$ & $(177) 94.2 \%$ & $(82) 100 \%$ \\
\hline & \multicolumn{2}{|l|}{ Undecided } & (4) $1.5 \%$ & (4) $2.1 \%$ & $(0) 0 \%$ \\
\hline & \multicolumn{2}{|l|}{ Disagree } & (8) $2.6 \%$ & (7) $3.7 \%$ & $(0) 0 \%$ \\
\hline \multirow{3}{*}{$\begin{array}{l}\text { b) An important and serious public } \\
\text { health issue in our country }\end{array}$} & \multicolumn{2}{|l|}{ Agree } & $(260) 96.3 \%$ & $(178) 94.6 \%$ & $(82) 100 \%$ \\
\hline & \multicolumn{2}{|l|}{ Undecided } & (5) $1.9 \%$ & (5) $2.7 \%$ & $(0) 0 \%$ \\
\hline & \multicolumn{2}{|l|}{ Disagree } & $(5) 1.8 \%$ & $(5) 2.7 \%$ & $(0) 0 \%$ \\
\hline \multirow{3}{*}{$\begin{array}{l}\text { c) An important and serious public } \\
\text { health issue in our hospital }\end{array}$} & \multicolumn{2}{|l|}{ Agree } & $(225) 83.3 \%$ & $(147) 78.2 \%$ & (78)95.2\% \\
\hline & \multicolumn{2}{|l|}{ Undecided } & $(38) 14.1 \%$ & $(34) 18.1 \%$ & (4) $4.8 \%$ \\
\hline & \multicolumn{2}{|l|}{ Disagree } & (7) $2.6 \%$ & (7) $3.7 \%$ & $(0) 0 \%$ \\
\hline & \multicolumn{2}{|c|}{ Incomplete course } & $(19) 7 \%$ & $(16) 8.5 \%$ & (3) $3.7 \%$ \\
\hline & \multicolumn{2}{|c|}{ Incorrect selection } & $(14) 5.2 \%$ & (9) $4.8 \%$ & $(5) 6 \%$ \\
\hline & Lower dosin & & (3) $1 \%$ & $(2) 1 \%$ & (1) $1.2 \%$ \\
\hline $\begin{array}{l}\text { 8. Cause or antimicrobial resistance } \\
\text { is/are }\end{array}$ & Poor Quality & & $0.00 \%$ & $0.00 \%$ & $0.00 \%$ \\
\hline & Over prescri & tion & (59) $21.9 \%$ & $(56) 29.8 \%$ & (3)3.7\% \\
\hline & All of above & & $(175) 64.9 \%$ & $(105) 55.9 \%$ & (70)85.4\% \\
\hline & None & & $0.00 \%$ & $0.00 \%$ & $0.00 \%$ \\
\hline
\end{tabular}

In practice part around $71 \%$ (192) of total participants stated that when they are prescribed an AMA and if after taking 2-3 doses they feel better they never stop taking further treatment. $68.6 \%$ (185) said that they never save the remaining AMA. 91.8\% (247) of study population always completed the full course of treatment. $97.8 \%$ (264) of participants always checked the expiry date before buying an AMA and $19.2 \%$ (52) of total responders used AMA when they have cough and sore throat and $50.8 \%$ (137) uncertain about it.

\section{DISCUSSION}

This study gives some good insight about the knowledge, attitude and practice of antimicrobial resistance and their usage among undergraduates and doctors in this hospital. In this study it is seen that majority of the students and doctors have good knowledge about antimicrobial resistance while attitude regarding the same is good in case of doctors but not so in case of undergraduates and regarding practice response rate is quite varied between undergraduates and doctors. In this study it has been found 
that $96.3 \%$ of total respondents agree that indiscriminate use of AMA leads to development of bacterial resistance and these results are consistent with similar studies done by Mahajan M et al, Tarao MS et al, and Akram A et al, but the study conducted by Afzal $\mathrm{K}$ et al, found that only $85 \%$ of total respondents believed that cause of bacterial resistance is due to its indiscriminate uses. ${ }^{6-9}$

Table 5: Participants attitude regarding antimicrobial resistance and usage $(n=270)$.

\begin{tabular}{|c|c|c|c|c|}
\hline & & Total (N)\% & Undergraduates (N)\% & Doctors (N)\% \\
\hline \multirow{3}{*}{$\begin{array}{l}\text { 1.Antimicrobials are safe drugs, hence they } \\
\text { can be commonly used medication }\end{array}$} & Agree & (102)37.8\% & (84) $44.7 \%$ & (21)25.6\% \\
\hline & Undecided & (20)7.4\% & (17)9\% & (3) $3.7 \%$ \\
\hline & Disagree & (148)54.8\% & (87)46.3\% & (58)70.70\% \\
\hline \multirow{3}{*}{$\begin{array}{l}\text { 2. Skipping one or two doses does not } \\
\text { contribute to the development of } \\
\text { antimicrobial resistance }\end{array}$} & Agree & (110)40.8\% & (83) $44.2 \%$ & (30)36.6\% \\
\hline & Undecided & (34) $12.6 \%$ & (23) $12.2 \%$ & (11) $13.4 \%$ \\
\hline & Disagree & $(126) 46.6 \%$ & $(82) 42.6 \%$ & $(41) 50 \%$ \\
\hline \multirow{3}{*}{$\begin{array}{l}\text { 3. Antimicrobial prescriptions should be } \\
\text { based on culture and sensitivity report }\end{array}$} & Agree & (250)92.7\% & $(172) 91.5 \%$ & (79) $96.3 \%$ \\
\hline & Undecided & (13)4.9\% & $(12) 6.3 \%$ & (1) $1.2 \%$ \\
\hline & Disagree & (7) $2.8 \%$ & (4) $2.2 \%$ & (2) $2.5 \%$ \\
\hline \multirow{3}{*}{$\begin{array}{l}\text { 4. Knowledge on rationale use of } \\
\text { antimicrobial is essential for all doctors, } \\
\text { nurses, pharmacist and health care providers }\end{array}$} & Agree & (260)96.3\% & (180)95.7\% & (80)97.5\% \\
\hline & Undecided & (8)3\% & (6) $3.2 \%$ & (2) $2.5 \%$ \\
\hline & Disagree & (2) $0.7 \%$ & (2) $1.1 \%$ & $0 \%$ \\
\hline \multirow{3}{*}{$\begin{array}{l}\text { 5. Do you think there is abuse of } \\
\text { antimicrobials }\end{array}$} & Agree & (199)73.7\% & $(130) 69 \%$ & $(72) 87.8 \%$ \\
\hline & Undecided & $(43) 15.9 \%$ & (34) $18.2 \%$ & (8)9.8\% \\
\hline & Disagree & (28) $10.4 \%$ & (24) $12.8 \%$ & (2) $2.4 \%$ \\
\hline \multirow{3}{*}{$\begin{array}{l}\text { 6. Is abuse of antimicrobials the main cause } \\
\text { of bacterial infection }\end{array}$} & Agree & (129)47.8\% & (96)50.9\% & $(47) 57.3 \%$ \\
\hline & Undecided & $(62) 23 \%$ & (49)26\% & (14) $17.1 \%$ \\
\hline & Disagree & (79) $29.2 \%$ & (43)23.1\% & (21) $25.6 \%$ \\
\hline \multirow{3}{*}{ 7. Can antimicrobial resistance affect health } & Agree & (255)94.4\% & (175)93.1\% & (80)97.5\% \\
\hline & Undecided & (9)3.4\% & (8) $4.3 \%$ & (1) $1.2 \%$ \\
\hline & Disagree & (6) $2.2 \%$ & $(5) 2.6 \%$ & (1) $1.3 \%$ \\
\hline
\end{tabular}

Table 6: Participants practice regarding antimicrobial resistance and usage $(n=270)$.

Total (N)\% Undergraduates (N)\% Doctors (N)\% 1. The doctor prescribes a course of antimicrobial for you. After taking 2-3 doses you start feeling better

- Do you stop taking further treatment?

- Do you save the remaining antibiotics for the next time you get sick?

- Do you discard remaining, left-over medication?

- Do you give the leftover antimicrobials to your friend/ roommate they get sick?

- Do you complete the full course of treatment?

2. Do you check the expiry date of antimicrobials before using it?

3. Do you prefer to take an antimicrobial when

you have cough and sore throat?

\begin{tabular}{llll} 
Yes & $(23) 8.6 \%$ & $(22) 11.7 \%$ & $(1) 1.2 \%$ \\
\hline Uncertain & $(55) 20.4 \%$ & $(43) 22.9 \%$ & $(12) 14.7 \%$ \\
\hline No & $(192) 71 \%$ & $(123) 65.4 \%$ & $(69) 84.1 \%$ \\
Yes & $(36) 13.3 \%$ & $(33) 17.6 \%$ & $(3) 3.6 \%$ \\
\hline Uncertain & $(49) 18.1 \%$ & $(39) 20.7 \%$ & $(10) 12.1 \%$ \\
\hline No & $(185) 68.6 \%$ & $(116) 61.7 \%$ & $(69) 84.1 \%$ \\
\hline Yes & $(63) 23.4 \%$ & $(36) 19.1 \%$ & $(27) 32.8 \%$ \\
\hline Uncertain & $(68) 25.2 \%$ & $(52) 27.7 \%$ & $(16) 19.6 \%$ \\
\hline No & $(139) 51.4 \%$ & $(100) 53.2 \%$ & $(39) 47.6 \%$ \\
\hline Yes & $(45) 16.7 \%$ & $(37) 19.7 \%$ & $(9) 9.8 \%$ \\
\hline Uncertain & $(77) 28.5 \%$ & $(61) 32.4 \%$ & $(16) 19.7 \%$ \\
\hline No & $(148) 54.8 \%$ & $(90) 47.9 \%$ & $(57) 70.5 \%$ \\
\hline Yes & $(248) 91.8 \%$ & $(168) 89.4 \%$ & $(80) 97.6 \%$ \\
\hline Uncertain & $(15) 5.6 \%$ & $(13) 7 \%$ & $(2) 2.4 \%$ \\
\hline No & $(7) 2.6 \%$ & $(7) 3.6 \%$ & $(0) 0 \%$ \\
\hline Yes & $(264) 97.8 \%$ & $(185) 98.4 \%$ & $(79) 96.3 \%$ \\
\hline Uncertain & $(0) 0 \%$ & $(0) 0 \%$ & $(0) 0 \%$ \\
\hline No & $(6) 2.2$ & $(3) 1.6 \%$ & $(3) 3.7 \%$ \\
\hline Yes & $(52) 19.2 \%$ & $(34) 18.1 \%$ & $(18) 22 \%$ \\
\hline Uncertain & $(137) 50.8 \%$ & $(99) 52.7 \%$ & $(38) 46.3 \%$ \\
\hline No & $(81) 30 \%$ & $(55) 29.2 \%$ & $(26) 31.7 \%$ \\
\hline
\end{tabular}


Also in this study it is seen that knowledge of doctors regarding emergence of bacterial resistance is better than undergraduates which is statistically significant. $91 \%$ of the total respondents in this study believe that ineffective treatment by AMA is due to its indiscriminate use which is consistent with the study conducted by Tarao MS et al, but it is found to be only $85 \%$ in study by Afzal K et al.,

Studies done previously by Zafar SN et al, showed that around $60 \%$ of the participants believed that antibiotics should be prescribed for viral diseases like sore throat and cough, and these type of belief can lead to usage of more and more antibiotics leading to bacterial resistance, while in this study only $30 \%$ of the total respondents believe that antibiotics should not be taken in cough and sore throat and around $51 \%$ is uncertain which is very surprising but around $89 \%$ are well aware that bacteria does not cause common cold and influenza. So proper education regarding practice of antibiotics is necessary. ${ }^{10}$

More than half of the respondents $(64.9 \%)$ in this study agree that main cause of antibiotic resistance are over prescription of antibiotics, poor quality, lower dosing, incomplete course and incorrect selection of antibiotics, whereas in the study conducted by Tarao MS et al, shows that $62.6 \%$ respondents believed that indiscriminate use of antibiotic is the main cause for its resistance respectively. When our participants are asked whether antimicrobial resistance can affect health $94.4 \%$ of the total respondents agree it which is similar to the findings of Ying $\mathrm{H}$ et al, where response rate for this was around $82 \%$ but the study conducted by Kamala $\mathrm{T}$ et al, found only $62.5 \%$ agreed that antibiotic resistance affect health. ${ }^{11,12}$

In this study it has been found that around $92 \%$ of the total respondents complete the full course of treatment after prescribing antibiotics which is consistent with other studies.

Around $71 \%$ of total population of this study never stop taking antibiotics in spite of feeling better after taking 2-3 doses of antibiotics which is almost similar to the findings conducted by Mahajan $\mathrm{M}$ et al, but the study conducted by Afzal $\mathrm{K}$ et al, found that only $55 \%$ never stop taking antibiotics in spite of feeling better after 2-3 doses. ${ }^{6,9}$ When asked whether they check the expiry date of antibiotics before buying it around $98 \%$ of the study population respond positively with similar response rate found in the study by Tarao MS et al, where response rate was $94 \% .^{7}$

Since now a day there is no restriction on Over The Counter (OTC) dispensing of antibiotics without prescriptions so any antibiotics can be purchased OTC without prescriptions. ${ }^{13,14}$ These kind of practices may cause abuse of antibiotics among the populations leading to development of resistance. In this study total $73.7 \%$ study population agree that there is abuse of antimicrobials with similar kind of results found in the study by Tarao MS et al. ${ }^{7}$

\section{CONCLUSION}

This study provides an important insight regarding knowledge, attitude and practices of antimicrobial resistance and usage among the undergraduates and doctors. It has been found in this study that there is need of education with more emphasis on the practice of antibiotic prescription rather than knowledge and attitude in both undergraduates and doctors.

\section{ACKNOWLEDGEMENTS}

Authors would like to thank the students and doctors who participated in the study for their input, dedication and enthusiasm.

\section{Funding: No funding sources Conflict of interest: None declared \\ Ethical approval: The study was approved by the Institutional Ethics Committee}

\section{REFERENCES}

1. Antimicrobials: An Introduction: Antimicrobial Resistance Learning sites for Veterinary Students. Available

at: https://amrls.cvm.msu.edu/pharmacology/antimicrobi als/antimicrobials-an-introduction. Accessed on 10 September 2017.

2. Tripathi KD, Antimicrobial drugs-General Considerations, Essentials of Medical Pharmacology, $7^{\text {th }}$ Edit, Jaypee, Chap 49; 2013:688.

3. Chen C, Chen YM, Hwang KL, Lin SJ, Yang CC, Tsay RW, Liu CE, Young TG. Behavior, attitudes and knowledge about antibiotic usage among residents of Changhua, Taiwan. J Microbiol Immunol Infect. 2005 Feb;38(1):53-9.

4. Srinivasan A, Song X, Richards A, SinkowitzCochranR, Cardo D, Rand C. A survey of knowledge, attitudes, and beliefs of house staff physicians from various specialties concerning antimicrobial use and resistance. Arch Intern Med. 2004;164:1451-6.

5. Brown EM. Guidelines for antibiotic usage in hospitals. J Antimic Chemother. 2002;49:587-92.

6. Manali M, Sujata D, Swapnil D. A Questionnaire based Survey on the Knowledge, Attitude and Practises about Antimicrobial Resistance and Usage among the Second year MBBS Students of a Teaching tertiary care Hospital in Central India. IJPR. 2014;4(4):175-80.

7. Tarao MS, Nulla P, Zingpi M, Agatha G. A Study on the Knowledge, Attitude, Perceptions and Practices of Antibiotic Usage and Resistance among the Medical Students of JNIMS, Imphal, Manipur. J Evi Based Med Healthca. August 2015;2(34):5262-8.

8. Akram A, Muhammad UK, Isha P, Sandeep M, Sureshwar P, Sameer D. Knowledge, attitude and practice of B.Sc. Pharmacy students about antibiotics in Trinidad and Tobago. Brief communication 2015;4(1):37-41. 
9. Khan A, Gausia B, Reshma K. Resistance and UsageA Survey on the Knowledge, Attitude, Perceptions and Practices among the Medical Students of a Southern Indian Teaching Hospital. JCDR. 2013 Aug;7(8):1613-6.

10. Zafar SN, Syed R, Waqar S, Zubairi AJ, Vaqar T, Shaikh M, et al. Self-medication amongst university students of Karachi: prevalence, knowledge and attitudes. Journal of the Pakistan Medical Association. 2008;58(4):214.

11. Ying H, Jiarui G, Mingyu Z, Zheng R, Weidong Y, Yang C, et al. Knowledge, attitude and practice of antibiotics: a questionnaire study among 2500 Chinese students. BMC Medical Education. 2013;13:163-72.

12. Thriemer K, Katuala Y, Batoko B, Alworonga JP, Devlieger $\mathrm{H}$, Van Geet C, et al. Antibiotic prescribing in DR Congo: a knowledge, attitude and practice survey among medical doctors and students. PloS one. 2013 Feb 18;8(2):e55495.
13. Rathnakar UP, Sharma NK, Garg R, Unnikrishnan B, Gopalakrishna HN. A study on the sale of antimicrobial agents without prescriptions in pharmacies in an urban area in South India. J Clin Diagn Res. 2012;6:951-4.

14. Saradamma RD, Higginbotham N, Nichter M. Social factors influencing the acquisition of antibiotics without prescription in Kerala State, South India. Soc Sci Med. 2000;50:891-903.

Cite this article as: Yashin AN, Thakuria N, Narzary H, Satnami D, Paul N. A questionnaire based survey on the knowledge, attitude and practices about antimicrobial resistance and usage among the MBBS students and doctors of a tertiary care teaching Hospital in Silchar, Assam, India. Int J Basic Clin Pharmacol 2018;7:1630-6. 